\title{
Kateryna Strohanova*
}

Uniwersytet im. Tarasa Szewczenki w Kijowie (Ukraina)

\section{Witold Gombrowicz na Ukrainie - przekłady, recepcja, przyszłość}

\section{Streszczenie:}

Kateryna Strohanova dokonuje w swoim artykule opisu oraz systematyzacji - wraz z wyszczególnieniem informacji o przekładach i recepcji (naukowo-krytyczno-literackiej) - twórczości Witolda Gombrowicza (1904-1969) w ukraińskiej przestrzeni kulturalnej. Opis dostępnych źródeł oraz ich uporządkowanie chronologiczne pozwoliły na całościowe przedstawienie recepcji Gombrowicza na Ukrainie. Pierwsza część tekstu badaczki zdaje krótką relację z historii przekładów utworów Gombrowicza na język ukraiński w latach 1989-2015, a druga z nich opisuje podstawowe reakcje krytyczno-literacko-publicystyczne na dzieła polskiego pisarza (zgodnie z chronologią ukazywania się translacji). Ostatnia opowiada zaś o ukraińskich pracach badawczych nad życiem i twórczością autora Trans-Atlantyku. Strohanova skłania się tu ku refleksji, że dorobek literacki Gombrowicza nie jest wystarczająco reprezentowany w ukraińskiej polonistyce i lukę tę należy jak najszybciej wypełnić.

Słowa-klucze: Witold Gombrowicz, przekład, recepcja, polonistyka ukraińska.

* Kateryna Strohanova - mgr; absolwentka polonistyki na Uniwersytecie Narodowym im. Tarasa Szewczenki w Kijowie; tłumacz, redaktor. 


\section{Witold Gombrowicz in Ukraine - translations, perception, future}

\section{Summary:}

In her article, Kateryna Strohanova describes and systemises the work of Witold Gombrowicz (1904-1969) in Ukrainian information space, together with specified information on translations and (scientific, critical, and literary) reception. The description of available sources and their chronological systemisation allow her to present the total reception of Gombrowicz in Ukraine. The first part of the author's text includes a short account of the history of translations of Gombrowicz's works into Ukrainian in the years 1989-2015. The second part aims to describe basic critical, literary and journalistic reactions to the works of the Polish writer (according to the chronology of translations as they were published). The last part describes Ukrainian research work on the life and work of the author of "Trans-Atlantyk". Here, Strohanova makes a reflection that Gombrowicz's work is not sufficiently represented in the Ukrainian Polish studies and this gap should be filled as quickly as possible.

Key words: Witold Gombrowicz, translation, reception, Polish studies in Ukraine.

Zainteresowanie literaturoznawstwa - polskiego i ukraińskiego - Witoldem Gombrowiczem jest zjawiskiem w XXI wieku szczególnie uzasadnionym. Dziś, gdy filozofia sztuki współczesnej stopniowo ciąży ku posthumanizmowi, moda na Gombrowicza staje się rzeczą całkiem zrozumiałą - przecież jako twórca nie tylko przekroczył on granice modernizmu, ale przewyższa kunsztem wielu wybitnych artystów postmodernistycznych. Przyjrzyjmy się zatem dorobkowi autora Ferdydurke na gruncie kultury ukraińskiej - a mówiąc precyzyjnie: przekładom jego dzieł oraz wypowiedziom krytyczno-literackim. Warto też dokonać pew- 
nej aktualizacji bibliograficznej, bowiem w przeciągu lat, które minęły od publikacji jedynego jak dotąd przeglądu bibliograficznego, dotyczącego recepcji Gombrowicza na Ukrainie autorstwa Olesi Nachlik w 2010 roku, pojawiło się trochę nowych tekstów omawiających ten temat.

\section{Przekłady}

Zacznijmy od bibliografii przekładów dorobku Gombrowicza, bowiem właśnie od translacji rozpoczęła się historia znajomości masowego czytelnika ukraińskiego z utworami tego pisarza. Po raz pierwszy słowo Gombrowicza pojawiło się na stronach, jeszcze radzieckich (bo z 1989 roku), ukraińskich gazet - chodzi konkretnie o czasopismo kulturologiczne „Ï”. Były to niewielkie fragmenty Dziennika, liczące zaledwie kilka stron opatrzonych krótkim komentarzem. Ich upublicznienie nastąpiło na fali euforii związanej z udostępnieniem Dziennika w Polsce. „Niedawno publiczności zaprezentowano Dzienniki już zmarłego pisarza, co stało się istotnym wydarzeniem w życiu kulturalnym Polski. Wydarzeniem niejednoznacznym, a nawet drastycznym" ${ }^{-1}$ informuje wspomniany komentarz, jaki dołączono do pierwszego wydania.

Po kilku latach przerwy, w 1992 roku, już w niezależnej Ukrainie, szanowany ukraiński magazyn literatury obcej „Wseswit” („Wszechświat”) drukuje Pronografie w tłumaczeniu Oleksandra Hrycenki, a także nieco obszerniejsze fragmenty Dziennika. Tłumacz dodał do tekstów artykuł Konstruktor „piekielnych maszyn”, w którym streścił życiorys Gombrowicza, opisał jego dorobek pisarski, historię przekładów, nakreślając dodatkowo kilka słów o paradygmacie filozofii pisarza. Hrycenko pisze: „,...] przedstawiając czytelnikowi ukraińskiemu to nieznane imię, musimy dodawać: jest jednym z największych pisarzy XX wieku"2. Przekład Pornografii był reakcją ukraińskiej wspólnoty polonistycznej na publikację tej powieści w krakowskim Wydawnictwie Literackim w 1990 roku.

1 В. Гомбрович, Щоденник. 1952-1956 (фрагменти), „Незалежний культурологічний часопис Ї” 1989, http://www.ji.lviv.ua/n1texts/gombrow.htm [dostęp: 22.02.2018 r.].

2 О. Гриценко, Конструктор “пекельних машин”, „Всесвіт” 1992, nr 10 (766), s. 4 . 
Pierwsze wydanie książkowe utworów Gombrowicza na Ukrainie to trzy tomy Dziennika w tłumaczeniu Roksany Charczuk. Projekt ów został zrealizowany przez kijowskie wydawnictwo Osnowy. Komentarz do Dziennika obrazowo opisuje wielkość autorytetu Gombrowicza dla ukraińskiego wydawcy, a więc, sugestywnie, też czytelnika:

Witold Gombrowicz określa oblicze literatury polskiej XX wieku. Jego powieści Ferdydurke, Trans-Atlantyk, Pornografia, Kosmos zostały przetłumaczone na wiele języków. Jednak za jeden z najważniejszych i najbardziej kontrowersyjnych utworów całej prozy polskiej można uważać jego Dziennik. Gombrowicz twardo i rygorystycznie podchodzi do najistotniejszych problemów polskiej historii, sztuki, myślenia polskiego oraz samego sposobu polskiego bytowania. W tej często bolesnej i nieprzyjemnej prawdzie o Polakach mogą poznać siebie też inne narodowości $i^{3}$.

W 2001 roku na ukraiński przełożono esej Gombrowicza pt. Przeciw poetom (ponownie przez Roksanę Charczuk) i wydano go w zbiorze 12 polskich esejów - obok tekstów Miłosza, Herberta i Bieńkowskiej. „Książka przygotowana przez znaną ukrainoznawczynię Olę Hnatiuk wspólnie z Mykołą Riabczukiem oraz młodymi tłumaczami - stypendystami Międzynarodowej Szkoły Humanistycznej Europy Środkowo-Wschodniej - jest pierwszą próbą systematycznego przedstawienia polskiej współczesnej tradycji umysłowej dla naszych czytelników"4 donosi recenzja wydawnictwa Krytyka.

Rok później, w 2002, Osnowy publikują kolejną książkę - mistrzowski przekład kultowej powieści Gombrowicza Ferdydurke. Do sprawy zabrał się publicysta i tłumacz Andrij Bondar, którego nazwisko jeszcze nieraz pojawi się na ukraińskojęzycznych stronach obok Gombrowicza. Tekst poprzedza krótki komentarz:

3 В. Гомбрович, Щоденник в 3-х томах: т. I - 1953-1956, т. II - 1957-1961, т. III - 1961-1969, пер. Р. Харчук, Київ: Основи 1999.

4 Чеслав Мілош, Єва Бєньковська, Збігнєв Герберт та ін. Дванадиять польських есеїв, Критика 2001. Zob. https://krytyka.com/ua/reviews/dvanadtsyat-polskykh-eseyiv. October 2001 [dostęp: 22.02.2018 r.]. 
Powieść Ferdydurke wybitnego polskiego pisarza Witolda Gombrowicza [...] to błyskotliwa i fascynująca wędrówka w świat ludzkich stereotypów - w opinii większości krytyków jest centralnym utworem literatury polskiej XX wieku. Prowokacyjno-awangardowy, bałaganowo-kabaretowy, parodyjnie-groteskowy, ironicznie-sceptyczny, stylistycznie rozmaity, utwór ten demonstruje wieczną dysharmonię istnienia człowieka, cały czas poszukujęcego własnej autentycznej formy ${ }^{5}$.

Po ukazaniu się Ferdydurke nastąpiły lata, a nawet dekady oczekiwania. Kolejne warte uwagi wydarzenie w historii ukraińskich przekładów Witolda Gombrowicza miało miejsce dopiero w 2015 roku, kiedy to projekt Biblioteka Babilońska we współpracy z lwowskim Wydawnictwem Starego Lwa wpisały powieść Pornografia na listę przygotowywanych do wydania klasyków światowych. Opublikowano istniejący przekład Oleksandra Hrycenki, ten, który w 1992 roku pojawił się na stronach czasopisma literackiego „Wseswit” - tekst opracowano, zredagowano, uzupełniono o ilustracje Jewhena Samborskiego. Roman Malinowski (koordynator projektu Biblioteka Babilońska) opowiada o procesie wydawniczym następująco:

Wybór był całkiem przypadkowy. Wzięliśmy się do istniejącego przekładu tej powieści, odnowiliśmy go, i tak się stało, że ten tekst jest teraz na czasie dla Ukrainy. [...] Gombrowicz - bo to jeden z najpotężniejszych umysłów światowych dwudziestego wieku. Za którą powieść się nie weźmiemy - Trans-Atlantyk, Ferdydurke, Pornografia, Dzienniki - każda z nich jest warta przetłumaczenia na każdy język świata. Naprawdę się cieszę, że Pornografia została na Ukrainie odkryta na nowo i po raz pierwszy ukazała się jako książka6.

To wydanie Pornografii okazało się prawdziwym hitem marketingowym - zarówno wśród czytelników, jak i krytyków literackich. Czasopisma internetowe mnożyły recenzje, a publicyści zwrócili się do zagranicz-

5 В. Гомбрович, Фердидурке, пер. А. Бондар, Київ: Основи 2002, 325 s.

6 Р. Малиновський, „Чому Гомбрович”. 3бруч, 2015. https://zbruc.eu/node/41015 2 September 2015 [dostęp: 22.02.2018 r.]. 
nych źródeł. Nazwisko Gombrowicza zestawiano z innymi powieściami Biblioteki Babilońskiej - Magiem Johna Fowlesa, Rzeźniq numer pięć Kurta Vonneguta, Wattem Samuela Becketta itd. Polskiego pisarza uznano

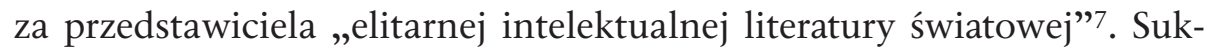
ces - czytelniczy i komercyjny - Pornografii zainspirował wydawców do publikacji kolejnej znaczącej powieści Gombrowicza - Trans-Atlantyku w tłumaczeniu Andrija Bondara. Tym razem książkę opublikowano poza projektem Biblioteki Babilońskiej, jako osobny tom. Przekład TransAtlantyku dał ukraińskiemu czytelnikowi możliwość bliższego zapoznania się z Gombrowiczem - polski pisarz stał się popularny.

W taki sposób dobre przekłady, rzetelnie sporządzone książki i wzorcowo przeprowadzone kampanie marketingowe wprowadziły Gombrowicza do szerokiego ukraińskiego kręgu czytelniczego. Widzimy jak nierównomierny to był, ale jednak postęp - od publikacji małych fragmentów Dziennika w późnej radzieckiej i wczesnej niezależnej ukraińskiej prasie do kunsztownych, wypromowanych wydań z 2015 roku. Nie mniej jednak, uwagi o elitarności dorobku Gombrowicza są bardzo słuszne - jego utwory nie każdy czytelnik rozumie w pełni (czy choćby częściowo). Powstała więc naturalna potrzeba krytyczno-literackich opracowań. Należało dokonać osobnych działań służących wprowadzeniu Gombrowicza w kontekst stricte naukowy, literaturoznawczy. Niestety w polonistyce ukraińskiej do dziś brak jest osobnych, obszerniejszych studiów rozjaśniających meandry jego twórczości. Mamy nadzieję, że tę lukę uda się szybko wypełnić.

\section{Krytyka literacka}

Powróćmy jednak do krytyki literackiej i tekstów publicystycznych poświęconych na Ukrainie utworom Gombrowicza. Zwykle wszystkie tego typu głosy związane są z ukazaniem się przekładów jego dzieł. Fragmenty Dziennika w czasopiśmie „Ï” zaopatrzono tylko w krótką adnotację, natomiast Pornografię i Dziennik w przekładzie Oleksandra Hrycenki z 1992 roku omówiono w artykule zamieszczonym w tym samym nume-

7 Tamże. 
rze „Wseswitu”, w którym pojawił się tekst Gombrowicza. Wspomniany już przeze mnie tekst pt. Konstruktor „piekielnych maszyn” to merytoryczny i trafny skrót życiorysu Witolda Gombrowicza, jego twórczości i podstawowych zasad światopoglądowych. Hrycenko po raz pierwszy powiedział na Ukrainie o niezwykłej wadze i uniwersalności utworów Gombrowicza. Przytaczając cytaty z Dziennika o polskiej dumie narodowej i jej iluzoryczności, zaznaczył jednocześnie, że:

Możemy tylko żałować, że do dziś nikt się nie odważył powiedzieć Ukraińcom takich gorzkich, ale sprawiedliwych słów. [...] Dziennik byłby dziś lekturą niezwykle korzystną dla czytelnika ukraińskiego, szczególnie inteligencji zanurzonej w burzliwe nurty problemów narodowych i państwotwórczych ${ }^{8}$.

Ta myśl wybrzmiała w 1992 roku. Dziś wydaje się ona bardzo aktualna i bolesna. Losy współczesnej Ukrainy potwierdzają wartościowość niełaskawych i tak uniwersalnych słów Gombrowicza. Jednak sądy pisarza cenne są nie tylko dla tożsamości narodowej:

Tworząc "piekielne maszyny”, dokonując striptizów psychologicznych, prowokując, Gombrowicz zmusza nas do spojrzenia w głębiny dusz własnych, spojzenia i uświadomienia sobie zarazem! - całej nieczystości i nieprzyjemności, na które zazwyczaj przymykamy oczy ${ }^{9}$

- pisze Oleksandr Hrycenko, i na tym kończy swój niezwykle wartościowy przegląd, który, niestety, nie został należycie rozpowszechniony, nie bardziej w każdym razie, niż wspomniana publikacja w czasopiśmie „Wseswit”.

Kolejnym powodem do krytyczno-literackiej dyskusji nad Gombrowiczem stał się następny przekład, tym razem przynoszący pierwsze wydanie książkowe Dziennika w 1999 roku. W środowisku ukraińskich krytyków pojawiło się kilka odezw. Zwróćmy uwagę zwłaszcza na recenzję trzytomowego wydania dzieł Gombrowicza pióra Ludmiły Taran, zamieszczoną w czasopiśmie „Dzerkalo Tyżnia” („Lustro Tygodnia”).

9 Tamże, s. 88. 
Recenzentka zaczęła od uwagi, że „nazwisko pisarza jest u nas do dziś prawie nieznane dla szerokich kół czytelników, którzy się interesują literaturą światową"10. W dalszej części wywodu pojawia się cytat tłumaczki Dzienników, Roksany Charczuk: „Swego czasu [połowa lat 80. XX wieku - K. S.] studiując polonistykę na uniwersytecie w Kijowie, zarówno ja, jak i moi koledzy ze studiów, nie mieliśmy pojęcia o tym, kim jest Gombrowicz, jaka jest jego rola i znaczenie w literaturze polskiej. Nikt nam o nim nie opowiadał"11. W recenzji pojawia się ocena wpływu Gombrowicza na czytelników i na współczesną mu Polskę (nie tylko zresztą Polskę), liczne cytaty z Dziennika i następująca uwaga: „Gombrowicz to niezależny od nikogo znawca, dociekliwy, ostry, paradoksalny, burzący autorytety. W jakim celu? W imię prawdziwej wolności umysłu, w imię uwolnienia rodzimej kultury od stereotypów i przesądów"12.

Cechą charakterystyczną recepcji Gombrowicza na Ukrainie jest to, że z czasem szybkość reakcji na jego dzieła oraz jej skala rosły. Każdy kolejny przekład utworów polskiego pisarza zachęcał krytykę do coraz żywszej i bardziej dogłębnej analizy twórczości autora Trans-Atlantyku, skutkiem czego ukraiński czytelnik coraz bardziej przyzwyczajał się do dźwięku tego nazwiska. Całkiem więc naturalne, że reakcja ukraińskiego środowiska krytyczno-literackiego na przekład Ferdydurke w 2002 roku była bardziej interesująca i owocna niż publikacja wcześniejszych translacji tekstów artysty. W „Lustrze Tygodnia” i dzienniku krytyczno-literackim „LitAkcent” pojawiły się wartościowe opinie i recenzje powieści, z grona których godne uwagi są zwłaszcza: Ten niezniszczalny Gombrowicz Andrija Bondara (tłumacza powieści), Ferdydurke: formuła prowokacji Serhija Jakowenki, czy też Ferdydurke. Siedemdziesiąt lat później Oleksandra Kłymenki.

W krótkim szkicu Ten niezniszczalny Gombrowicz tłumacz Ferdydurke wypowiada kilka ważnych, zasadniczych dla dalszej recepcji utworów pisarza myśli:

10 Л. Таран, Гомбрович в Києві (Про презентацію тритомного видання “Щоденника” В. Гомбровича), „Дзеркало тижня” 2000, nr 8.

11 Tamże.

12 Tamże. 
W Polsce istnieje kult Gombrowicza, ale to kult jakiś dziwny, niekultowy. To nie Sienkiewicz, nie Kochanowski, nie Słowacki i nawet nie Mickiewicz. [...] Z Gombrowiczem jest dużo trudniej. To anty-Mickiewicz i anty-Słowacki. To pierwszy polski pisarz, który potrafił powiedzieć Polakom prawdę o nich ${ }^{13}$.

Bondar rozważa wpływ filozofii Gombrowicza na tożsamość Polaków. Dywaguje nad jego rolą w rozwoju kultury polskiej, i, jak swego czasu Hrycenko w Konstruktorze „piekielnych maszyn”, wnioskuje o tym, że Ukraina bardzo potrzebuje własnego Gombrowicza:

Nie mieliśmy pisarza o takiej „chirurgicznej”, „aborcyjnej” sile. Jeszcze nikt nie odważył się naprawdę dotknąć naszej ukraińskiej współczesności tak mocno, jak to zrobił pan Witold ${ }^{14}$.

Jednocześnie krytyk podsuwa sugestię, że być może Gombrowicz jest wystarczająco uniwersalny, aby uznać go za rodzimego autora-,,chirurga" współczesnej kultury:

Ale czy potrzebujemy „kogoś”? Przecież [...] jeśli zamienić w tekście rzeczownik „Polska” na „Ukraina”, przymiotnik „polski” na „ukraiński”, otrzymamy niby historię o sobie ${ }^{15}$.

Serhij Jakowenko - w napisanej w filozoficzno-literackiej tonacji recenzji - jako pierwszy zwraca się ku bardzo istotnemu problemowi: specyfice tłumaczenia gombrowiczowych tekstów, bardzo zawikłanych, mieszczących karkołomne sensy, grę słów i pozornie nieprzetłumaczalne elementy:

Co znaczy przetłumaczyć Ferdydurke na ukraiński? To wcale nie znaczy - przetłumaczyć z polskiego. To znaczy stać się wojownikiem i odbyć krwawą wojnę z mową, która jest raczej Gombrowiczowa, niż polska. Chodzi o utwór, w którym fabuła pozostaje oparta wyłącznie na transmutacjach znaczeniowych oraz związ-

13 А. Бондар, Цей незнищенний Гомбрович, „Дзеркало тижня” 2002, nr (417).

14 Tamże.

15 Tamże. 
kach frazeologicznych. Chodzi o utwór jako teatr językowy i defiladę znaczeń. Dla tłumacza ważne było nie tylko znieść tortury, mękę i ból języka, trzeba było, żeby one przeszły na ukraińskiego czytelnika nie tracąc przy tym na znaczeniu pierwotnym, źródłowym, zaostrzonym, żeby czytelnik też poczuł na sobie ten słodki gwałt ducha, uchwycił ten masochizm i nauczył się nim upajać ${ }^{16}$.

Oleksandr Kłymenko w artykule z 2008 roku dla czasopisma „LitAkcent" krótko opisuje zawikłaną historię publikacji utworów Gombrowicza w Polsce i skupia się na koncepcjach filozofii pisarza oraz ich projekcji na teraźniejszość.

W okresie wspomnianej długiej przerwy między ukazywaniem się u nas poszczególnych przekładów Gombrowicza na język ukraiński powstał artykuł Wasyla Machna Historia z Gombrowiczem, będący esejem inspirowanym własnymi wspomnieniami i pracą - rozmyślaniami o losach pisarza-emigranta i jego utworach.

Prawdziwy „gombrowiczowski boom” nadszedł po publikacji Pornografii w ramach projektu Biblioteka Babilońska. Powstały wówczas liczne recenzje, opinie, szkice i omówienia twórczości polskiego pisarza. Jako pierwsi zareagowali krytycy w „Czytomo” - popularnym ukraińskim czasopiśmie internetowym poświęconym literaturze. Tetiana Kałytenko w swojej recenzji spróbowała odszyfrować niezrozumiałe dla przeciętnego czytelnika treści i na koniec sformułowała własne rekomendacje:

Polecam do przeczytania: jeśli uważacie, że świat jest pełen sugestii; polonistom; intuicjonistom; jeśli Historia oka Bataille'a - to nie tylko hardkor i porno; w stanie półsennym. Nie zaleca się czytać: poszukiwaczom porno; szukajwcym powieści o wojnie; wielbicielom powieści miłosnych ${ }^{17}$.

Wartościowy okazał się wywiad dziennika „Zbrucz” z Romanem Malinowskim - jednym z organizatorów procesu wydawniczego Bibliote-

16 С. Яковенко, “Фердидурке”: формула провокації, „Дзеркало тижня” 2002, nr 15 (390).

17 Т. Калитенко, “Порнографія" Гомбровича: виростити у гріхопадінні свого Бога, „Читомо” 2015. http://www.chytomo.com/issued/pornografiya-g-ombrovichavirostiti-u-grixopadinni-svogo-boga 14 August 2015 [dostęp: 22.02.2018 r.]. 
ki Babilońskiej. Malinowski opowiedział o przyczynie wyboru powieści Gombrowicza do publikacji w ramach serii oraz o specyfice poszukiwania i redagowania tekstu.

W 2015 roku pojawiła się również w czasopiśmie internetowym „5books" recenzja pióra Andrija Mielnika, w której dość trafnie oceniał on sukces komercyjny książki i nieoczekiwaną jej popularność wśród czytelników:

Czarna okładka i kuszący, zabroniony, intymny (dla odbiorców w wieku 17-21 lat) napis na stronie głównej - to było po prostu 10 na 10 od Wydawnictwa Starego Lwa. W księgarniach od razu po Forum Wydawców książkę brali w ręce najczęściej młodzi (czasem aż nazbyt młodzi) czytelnicy i czytelniczki, którzy nie mieli zielonego pojęcia o Gombrowiczu i w ogóle o literaturze polskiej (nie ma co mówić już o jakiejś Polsce czasów wojny, Armii Krajowej czy w ogóle o tym, jak skojarzyć ten skandaliczny wyraz na okładce z zawartością dwustu stron pod okładką - przecież żadnej wstydliwej czynności [...] w książce się nie ma) ${ }^{18}$.

Właśnie ten sukces uczynił nazwisko Gombrowicza naprawdę popularnym w szerokich kręgach czytelników ukraińskich - mimo że znaczna część przypadkowych odbiorców nie rozumiała ani motywacji pikantnego tytułu, ani samego tekstu. Jednak społeczność czytelnicza była nim zachwycona. Następny przekład książkowy - Trans-Atlantyk - też cieszył się u nas dużym zainteresowaniem. Trans-Atlantyk zyskał oddźwięk w środowisku recenzentów zwłaszcza w tygodniku „Druh czytelnika”. Oleh Kocarew pisał bowiem w nim o znaczeniu tego przekładu dla literatury ukraińskiej:

Ukazanie się w Wydawnictwie Starego Lwa ukraińskiego przekładu powieści Trans-Atlantyk wybitnego polskiego pisarza XX wieku Witolda Gombrowicza można w pewnym sensie porównać do analogicznego ukazania się ukraińskiego Ulissesa Joyce'a (i trochę późniejszego Watta Becketta). Oczywiście, porównanie jest ogólne, skala bardzo się różni. Jednak istnieje między nimi swoista bliskość estetyczna, wspólna chwytliwość. Zresztą, to jest bardzo ważne przeniknięcie

18 А. Мельник, “Порнограбія" Гомбровича як польська готика емоцій після aкmy, „5books” 2015: http://www.5books. org/2015/10/gombrovych.html 11 October 2015 [dostęp: 22.02 .2018 r.]. 
literatury wysokiego modernizmu w informacyjną przestrzeń ukraińskojęzyczną, w której taki proces nie zachodzi zbyt często ${ }^{19}$.

Skromniej i prościej mówił o powieści Mykoła Petraszczuk:

Powieść Gombrowicza Trans-Atlantyk zainteresuje intelektualnego czytelnika, który nie boi się eksperymentów literackich i lubi czytać wnikliwie oraz powoli ${ }^{20}$.

Artykuł o książkowych przekładach utworów Gombrowicza na Ukrainie pojawił się również na blogu BBC Ukraina i fakt ten możemy uważać za opis kierunku, w którym zmierza recepcja twórczości i postaci Gombrowicza na Ukrainie:

Witolda Gombrowicza uważa się za klasyka literatury polskiej. Jest on jednocześnie jednym z najtrudniejszych pisarzy XX wieku, którego twórczość pasuje dla wymagającego intelektualisty. Ona wymaga ambitnego czytelnika, który potrafi nie tylko zauważyć wielowarstwowość autorskich treści i metaforyki, ale też nie zgubić nici logiki i zdrowego rozsądku w świecie groteski oraz surrealizmu²1.

\section{Recepcja naukowa}

Recepcja twórczości Gombrowicza na Ukrainie pozostaje dla polonistyki ukraińskiej szerokim, niezbadanym i nieopisanym terenem. Szczególnie widać to na tle olbrzymiej ilości publikacji naukowych poświęconych Gombrowiczowi w Polsce, zwłaszcza jeśli chodzi o ostatnie dziesięciolecia XX wieku i pierwsze dziesięciolecie stulecia obecnego. O Gombrowiczu napisano mnóstwo artykułów i monografii. Wydawano

19 О. Коцарев, “Транс-Атлантик”: польський модернізм для украӥнського читача, „Друг читача” 2016: https://vsiknygy.net.ua/shcho_pochytaty/review/44401/ 19 April 2016 [dostęp: 22.02.2018 r.].

20 М. Петращук, “Транс-Атлантик” Гомбровича - яскравий приклад модернізму в польській літературі”, „Буквоїд” 2016: http://bukvoid.com.ua/reviews/books /2016/06/21/072746.html 21 June 2016 [dostęp: 22.02.2018 r.].

21 С. Самохіна, „Книжковий блог: світ патологій Гомбровича”, [w:] ВВС Украӥна. 2016: http://www.bbc.com/ukrainian/blogs/2016/09/160916_book_blog_ko 18 September 2016 [dostęp: 22.02.2018 r.]. 
specjalne numery kwartalników i zbiory szkiców naukowych. Badano jego filozofię, biografię, język. Na Ukrainie te prace się nie ukazały nawet w przekładzie.

Jednak pustka w kwestii badań nad twórczością Gombrowicza na Ukrainie nie jest całkowita - w 2007 roku wspomniany już Serhij Jakowenko napisał artykuł Czesław Miłosz i Witold Gombrowicz: między Wschodem a Zachodem, między domem a bezdomnościa. W 2010 roku na stronach „Kijowskich Studiów Polonistycznych” ukazał się podobny do mojego artykuł Ołesi Nachlik pt. Nieklasyczny klasyk. Utwory Witolda Gombrowicza na Ukrainie. Stał się on inspiracją do bardziej dogłębnego rozpatrzenia i chronologizacji tego tematu. Z niewiadomych przyczyn zabrakło $\mathrm{w}$ tym przeglądzie wspomnianego artykułu Jakowenki. To niedopatrzenie udało się naprawić w tekście niniejszym.

Artykuł Jakowenki to gruntowne studium komparatystyczne poświęcone koncepcjom domu i ojczyzny w światopoglądach Czesława Miłosza i Witolda Gombrowicza. Krytyk dokonuje tutaj interpretacji porównawczej wątku rodziny i gniazda rodzinnego w twórczości obu pisarzy, korzystając zwłaszcza z danych biograficznych. Większość jego uwagi badawczej przyciąga rola emigracji w życiu i kształtowaniu się twórczej wizji świata Gombrowicza i Miłosza. Badacz wnioskuje, że pierwszemu z nich udało się „zostać krytykiem polskości bez przejściowych symptomów potocznej sytuacji politycznej"22. Jakowenko analizuje Dzienniki Gombrowicza z okresu jego pobytu w Argentynie, Berlinie i Paryżu. Sięga do prac polskich i zagranicznych polonistów. Ostatni jego wniosek, raczej moralno-etyczny niż literaturoznawczy, brzmi następująco: Miłosz i Gombrowicz doświadczyli tych samych problemów, losu człowieka, który szuka swojego miejsca we wszechświecie, ale radzili sobie z nim na zupełnie różne sposoby.

Artykuł Serhija Jakowenki nie jest chronologicznie paralelny z przekładami utworów Gombrowicza na Ukrainie. Badacz poznawał twórczość pisarza $\mathrm{w}$ oryginale. Tekst krytyka stanowi cenne potwierdzenie dalszych tego typu kwerend nad dorobkiem Gombrowicza w polonistyce ukraińskiej.

22 С. Яковенко, Чеслав Мілош і Вітольд Гомбрович: між Сходом і Заходом, між домом і бездомністю, „Українська полоністика” 2007, nr 3-4, s. 285-295. 
Zapytajmy na koniec: czy Gombrowicz interesuje Ukraińców? Niewątpliwie tak. Czy wystarczająco dużo napisano i powiedziano o nim? Niewątpliwie nie. Sukces przekładów jego powieści świadczy o tym, że ukraiński czytelnik jest przygotowany do literatury elitarnej, należycie wykształcony, żeby ją zrozumieć. Jednak nie jest on jeszcze uzbrojony metodologicznie - ukraińska polonistyka literaturoznawcza potrzebuje gombrowiczowskiego tematu, bez niego traci olbrzymią część kultury umysłowej Polski (i czy tylko Polski?) burzliwego XX wieku. Aby skutecznie wprowadzić twórczość Gombrowicza w krąg zainteresowań naukowych Ukrainy, musimy zrealizować wiele zadań przygotowawczych: popularyzować polską literaturę, uświadomić, na czym polega i w czym przejawia się uniwersalność twórczości Gombrowicza, analizować swoją teraźniejszość przez pryzmat „naród - emigracja - tożsamość". Dlatego Gombrowicz powinien obowiązkowo pojawić się w polonistyce ukraińskiej.

\section{Literatura}

Бондар Андрій, Цей незнищенний Ґомбрович, „Дзеркало тижня” 2002, nr (417). Гриценко Олександр, Конструктор „пекельних машин”, „Всесвіт” 1992, nr 10 (766), s. 4.

Ґомбрович Вітольд, Фердидурке, пер. Андрій Бондар, Київ: Основи 2002, 325 s.

Ґомбрович Вітольд, „Щоденник. 1952-1956 (фрагменти)”. Незалежний культурологічний часопис „Ï”. 1989. Protokół dostępu: http://www.ji.lviv.ua/ n1texts/gombrow.htm [dostęp: 22.02.2018 r.].

Ґомбрович Вітольд, Щоденник в 3-х томах: т. I - 1953-1956, т. II - 1957-1961, т. III - 1961-1969, пер. Роксана Борисівна Харчук, Київ: Основи 1999.

Калитенко Тетяна, „Порнографія” Ґомбровича: виростити у гріхопадінні свого Бога". Читомо. 2015. Protokół dostępu: http://www.chytomo. com/issued/pornografiya-g-ombrovicha-virostiti-u-grixopadinni-svogoboga 14 August 2015 [dostęp: 22.02.2018 r.]. 
Коцарев Олег, „Транс-Атлантик”: польський модернізм для українського читача". Друг читача. 2016. Protokół dostępu: https://vsiknygy.net.ua/shcho_ pochytaty/review/44401/ 19 April 2016 [dostęp: 22.02.2018 r.].

Малиновський Роман, „Чому Ґомбрович”. Збруч. 2015. Protokół dostępu: https:// zbruc.eu/node/41015 2 September 2015 [dostęp: 22.02.2018 r.].

Мельник Андрій, „Порнографія” Ґомбровича як польська готика емоцій після акту". 5books. 2015. Protokół dostępu: http://www.5books.org/2015/10/gombrovych.html 11 October 2015 [dostęp: 22.02.2018 r.].

Нахлік Олеся, Некласичний класик. Твори Вітольда Гомбровича в Україні, Літературознавчі обрії: праці молодих учених 2010, nr 16, s. 121-126.

Петращук Микола, „Транс-Атлантик” Ґомбровича - яскравий приклад модернізму в польській літературі". Буквоїд. 2016. Protokół dostępu: http:// bukvoid.com.ua/reviews/books/2016/06/ http://bukvoid.com.ua/reviews/books/2016/06/ 21/072746.html 21 June 2016 [dostęp: 22.02.2018 r.].

Самохіна Світлана, „Книжковий блог: світ патологій Ґомбровича”. ВВС Україна. 2016. Protokół dostępu: http://www.bbc.com/ukrainian/blogs/2016/09/ 160916_book_blog_ko 18 September 2016 [dostęp: 22.02 .2018 r.].

Таран Людмила, Ґомбрович в Києві (Про презентацію тритомного видання „Щоденника" В. Ґомбровича), „Дзеркало тижня” 2000, nr 8.

„Чеслав Мілош, Єва Бєньковська, Збіґнєв Герберт та ін. Дванадцять польських есеїв". Критика. 2001. Protokół dostępu: https://krytyka.com/ua/reviews/dvanadtsyat-polskykh-eseyiv. October 2001 [dostęp: 22.02.2018 r.].

Яковенко Сергій, „Фердидурке”: формула провокації, „Дзеркало тижня” 2002, $\mathrm{nr} 15$ (390).

Яковенко Сергій, Чеслав Мілош і Вітольд Ґомбрович: між Сходом і Заходом, між домом і бездомністю, Українська полоністика 2007, nr 3-4, s. 285-295.

\section{Bibliografia}

Bondar Andrijj, Cejj neznishhennijj Gombrovich, „Dzerkalo tizhnja” 2002, nr (417). "Cheslav Milosh, Eva Benkovska, Zbiґn€v Gerbert ta in. Dvanadcjat polskikh eseïv". Kritika. 2001. Protokół dostępu: https://krytyka.com/ua/reviews/ dvanadtsyat-polskykh-eseyiv. October 2001 [dostęp: 22.02.2018 r.].

Gombrovich Vitold, Ferdidurke, per. Andrijj Bondar, Kiïv: Osnovi 2002, 325 s.

Gombrovich Vitold, „Ŝodennik. 1952-1956(fragmenti)”. Nezalezhnijjkulturologichnijj 
chasopis „Ï". 1989. Protokół dostępu: http://www.ji.lviv.ua/n1texts/gombrow.htm [dostęp: 22.02.2018 r.].

Gombrovich Vitold, Ŝodennik v 3-kh tomakh: t. I - 1953-1956, t. II - 1957-1961, t. III - 1961-1969, per. Roksana Borisivna Kharchuk, Kiïv: Osnovi 1999.

Gricenko Oleksandr, Konstruktor „pekelnikh mashin”, „Vsesvit” 1992, nr 10 (766), S. 4.

Jakovenko Sergijj, „Ferdidurke”: formula provokaciï, „Dzerkalo tizhnja” 2002, nr 15 (390).

Jakovenko Sergijj, Cheslav Milosh i Vitold Gombrovich: mizh Skhodom i Zakhodom, mizh domom i bezdomnistju, Ukraïnska polonistika 2007, nr 3-4, s. 285-295.

Kalitenko Tetjana, „Pornografija” Gombrovicha: virostiti u grikhopadinni svogo Boga". Chitomo. 2015. Protokół dostępu: http://www.chytomo.com/ issued/pornografiya-g-ombrovicha-virostiti-u-grixopadinni-svogoboga 14 August 2015 [dostęp: 22.02.2018 r.].

Kocarev Oleg, „Trans-Atlantik": polskijj modernizm dlja ukraïnskogo chitacha”. Drug chitacha. 2016. Protokół dostępu: https://vsiknygy.net.ua/shcho_pochytaty/ review/44401/ 19 April 2016 [dostęp: 22.02.2018 r.].

Malinovskijj Roman, „Chomu Gombrovich”. Zbruch. 2015. Protokół dostępu: https:// zbruc.eu/node/41015 2 September 2015 [dostęp: 22.02.2018 r.].

MelnikAndrijj, „Pornografija” Gombrovicha jak polska gotika emocijj pislja aktu”. 5books. 2015. Protokół dostępu: http://www.5books.org/2015/10/gombrovych.html 11 October 2015 [dostęp: 22.02.2018 r.].

Nakhlik Olesja, Neklasichnijj klasik. Tvori Vitolda Gombrovicha v Ukraïni, Literaturoznavchi obriï: praci molodikh uchenikh 2010, nr 16, s. 121-126.

Petraŝuk Mikola, „Trans-Atlantik” Gombrovicha - jaskravijj priklad modernizmu v polskijj literaturi". Bukvoïd. 2016. Protokół dostępu: http://bukvoid.com.ua/reviews/ books/2016/06/21/072746.html 21 June 2016 [dostęp: 22.02.2018 r.].

Samokhina Svitlana, „Knizhkovijj blog: svit patologijj Gombrovicha”. VVS Ukraïna. 2016. Protokół dostępu: http://www.bbc.com/ukrainian/blogs/2016/09/160916_ book_blog_ko 18 September 2016 [dostęp: 22.02.2018 r.].

Taran Ljudmila, Gombrovich v Kiєvi (Pro prezentaciju tritomnogo vidannja „Ŝodennika” V. Gombrovicha), „Dzerkalo tizhnja” 2000, nr 8. 